\title{
Influence of process conditions on the mass transfer of osmotically dehydrated jambolan fruits
}

\author{
Adriano Lucena de ARAÚJO ${ }^{1}$, Rosinelson da Silva PENA ${ }^{1,2 *}$ (D)
}

\begin{abstract}
Jambolan (Syzygium cumini) is a tropical fruit rich in anthocyanin pigments, but its fragile skin and pulp present low protection against physical damages and microorganisms. In this sense, a preservative technology, as osmotic dehydration (OD), was studied to investigate the impact of some variables over this process. At first, fruits of jambolan were submitted to physical and physicalchemical analysis. Furthermore, whole fruits underwent OD following a fractional factorial design. The influence of the process variables: temperature $\left(20-50^{\circ} \mathrm{C}\right)$, sucrose concentration (30-60\%), pressure (10-90 $\left.\mathrm{kPa}\right)$, vacuum pulse time (5-15 min), calcium lactate concentration (0-4\%) and number of vacuum pulse (1-3) was assessed on water loss (WL), solid gain (SG) and weight reduction (WR). In general, biometric analysis showed positive and significant correlation among the physical characteristics of jambolan. Physical-chemical assay demonstrated that the fresh fruit presents a potential source of bioactive compounds. The screening design showed that temperature, sucrose concentration, calcium lactate concentration and pressure affected the WL in jambolan. On the other hand, vacuum pulse time and number of vacuum pulse showed no influence on the WL, SG and WR; therefore, these variables must be fixed at the most economically viable level for any further trials.
\end{abstract}

Keywords: dehydration; morphometric characteristic; design of experiments.

Practical Application: The present work can improve the control of the unitary operation (dehydration) in OD of jambolan.

\section{Introduction}

The Amazon hosts a large biological diversity, including great number of non-native plant species, which have been successfully adapted to the Amazonian environmental conditions (Brito et al., 2017). Native from India, jambolan, janun or black plum (Syzygium cumini) fruits are ellipsoid berries from the Myrtaceae family, which present themselves as purplish black, with a sour taste at the ripe stages of maturation (Seraglio et al., 2018). This tropical fruit is also rich in anthocyanin pigments, especially in its peel (Sari et al., 2012).

However, the relatively short shelf life of fresh fruits after harvesting indicates the need for developing an efficient and cheap preservation process. Besides, the rising search for products with similar sensory and nutritional properties to fresh fruits also stimulates the food industry to seek for preservation methods in foods (Sridevi \& Genitha, 2012). In this scenario, osmotic dehydration (OD) is growing as a popular technique for obtaining processed fruits, improving their quality and stability (Ahmed et al., 2016).

Commonly, OD is a pre-treatment prior to air-drying. This technique is based on the immersion of fruits in hypertonic solution for partial water removal. The driving force for its removal is the difference in osmotic pressure between the fruit and the hypertonic solution. The fruit's complex cell structure acts as a semi-permeable membrane, generating extra resistance to water diffusion within the fruit. This mass transfer depends on some factors, such as the product's geometry, temperature, addition of salts and concentration of the osmotic solution, among others (Torreggiani, 1993).

Traditionally, the osmotic process is employed at atmospheric pressure; however, in recent decades, it has been combined with other innovative techniques, such as vacuum application, which can enhance its efficiency and improve the quality of the product (Ahmed et al., 2016). Some researchers have studied the use of vacuum in OD to accelerate mass transfer in products such as guavas (Corrêa et al., 2010) and tomato (Corrêa et al., 2015), among other works involving the study of vacuum pulse time (Ito et al., 2007) and number of vacuum pulse (Zapata et al., 2016).

Due to the perishability of jambolan, especially by the fragility of its skin and pulp, that offer low protection against mechanical damages and infectious agents, harvest and postharvest management are essential for extending the fruit's shelf life. In this sense, some studies have assessed the drying of jambolan fruit using different techniques, including air forced drying (Kapoor et al., 2015), foam mat drying (Carvalho et al., 2017) and spray-drying (Singh et al., 2019). However, no studies have been reported regarding OD techniques for jambolan fruits.

In this context, the objectives of this work were to assess the physical and physical-chemical characterization of jambolan, as well as to use a fractional factorial design for investigating the 
influence of variables as temperature, sucrose concentration, pressure, vacuum pulse time, calcium lactate concentration and number of vacuum pulse on the responses water loss, solid gain and weight reduction, during the osmotic dehydration of this fruit.

\section{Material and methods}

\subsection{Raw material}

Mature fruits of jambolan (Syzygium cumini) were collected from a tree located at the Federal University of Para, in the city of Belem, state of Para, Brazil (latitude $1^{\circ} 28^{\prime}$ S, longitude $48^{\circ} 29^{\prime} \mathrm{W}$ ), during the rainy season, in December 2019. The regional climate is tropical monsoon and the average annual air temperature is $26^{\circ} \mathrm{C}$ (ranging from $22^{\circ} \mathrm{C}$ to $31.5^{\circ} \mathrm{C}$ ). The average annual precipitation is $3000 \mathrm{~mm}$, including daily precipitations above $25 \mathrm{~mm}$ (Instituto Nacional de Meteorologia, 1992).

The fruits were transported in polystyrene isothermal boxes to the Laboratory of fruits, at the Federal University of Para. The jambolan fruits were selected based on the maturation stage, absence of physical damages and rot; then, the selected fruits were rinsed in running water, sanitized by immersion in hypochlorite solution at $20 \mathrm{mg} / \mathrm{L}$, during 15 minutes, followed by rinsing. One hundred units of these fruits were separated for biometric analysis, shortly after harvesting. In addition, the sanitized fruits were packaged in small quantities $(\approx 100 \mathrm{~g})$ in polypropylene pots coated with aluminum foil, which were frozen in a vertical ultra-freezer (CL374-80, Coldlab, Brazil) at $-70{ }^{\circ} \mathrm{C}$. Then, the frozen fruits were stored at $-18{ }^{\circ} \mathrm{C}$, until physical-chemical and osmotic dehydration analysis.

\subsection{Biometric analysis}

The biometric analysis was performed individually with 100 fresh jambolan fruits. The morphometric characteristics (longitudinal and equatorial diameter) of the whole fruit were determined using a caliper (235, WESTERN, China) with $0.05 \mathrm{~mm}$ resolution and the results were expressed in $\mathrm{mm}$. The whole fruit, seed and pulp weight (in grams) were obtained by individual weighing in a digital precision balance (M214AIH, BEL, Brazil), with $0.0001 \mathrm{~g}$ accuracy. The yield, expressed as percentage, was calculated by the Equation 1 .

$Y=\left(\frac{W_{c} \times 100}{W_{f}}\right)$

where $\mathrm{Y}=$ yield (\%); $\mathrm{W}_{\mathrm{c}}=$ weight of the pulp $(\mathrm{g}) ; \mathrm{W}_{\mathrm{f}}=$ weight of the whole fruit $(\mathrm{g})$.

\subsection{Physical-chemical, chemical and color analysis}

Jambolan fruits (epicarp + mesocarp) were submitted to the following analyzes: moisture (n. 920.151), ashes (n. 940.26), total proteins (n. 920.152), total lipids (n. 922.06), pH (n. 943.15), and total titratable acidity (n. 942.15). All measurements were performed according to the Association of Official Analytical Chemists (2002) methodology. The carbohydrates were calculated by the difference between 100 and the sum of the percentage of moisture, total proteins, total lipids and ashes
(Food and Agriculture Organization of the United Nations, 2003). Meanwhile, reducing sugars was determined by dinitrosalicylic acid reagent (Miller, 1959); monomeric anthocyanins were determined according to the method of Lees \& Francis (1972) and total phenolics using the Folin-Ciocalteu method (Singleton \& Rossi, 1965). The monomeric anthocyanins and total phenolics were expressed as $\mathrm{mg} \cdot 100^{-1} \mathrm{~g}$ and as gallic acid equivalents (mg GAE. $\left.100^{-1} \mathrm{~g}\right)$, respectively. Water activity $\left(\mathrm{a}_{\mathrm{w}}\right)$ was measured at $25^{\circ} \mathrm{C}$ using a thermohygrometer (Aqualab 4TE, Decagon, USA). Color parameters for $\mathrm{L}^{*}$ (lightness), $\mathrm{a}^{\star}$ (redness $\mid$ greenness), $\mathrm{b}^{\star}$ (yellowness $\mid$ blueness), $\mathrm{C}^{*}$ (chroma - color intensity) and $\mathrm{h}^{\circ}$ (hue angle - values of $0^{\circ}, 90^{\circ}, 180^{\circ}$ and $270^{\circ}$ denote pure red, pure yellow, pure green, and pure blue colors, respectively) were measured using a digital colorimeter (Minolta CR-400, Konica, Japan) calibrated with white plate, using the CIE standard D65 illuminant and CIE 1964 observed $\left(10^{\circ}\right.$ visual field). All data were obtained by triplicate analyses and expressed as mean \pm standard deviation.

\subsection{Fractional factorial design}

A fractional factorial design was applied to study the main effects of the independent variables temperature $(\mathrm{T})$, sucrose concentration $(\mathrm{SC})$, pressure $(\mathrm{P})$, vacuum pulse time $(\mathrm{PT})$, calcium lactate concentration (CC) and number of vacuum pulse (N) on the dependent variables water loss (WL), solid gain (SG) and weight reduction (WR); in the osmotic dehydration (OD) process of the jambolan. The OD followed a $2^{6-2}$ design with 19 assays: 16 linear assays (at -1 and +1 levels) and 3 assays in the central point (all independent variables at level 0 ). The aim of this technique is to reduce the number of experimental runs when several variables are analyzed simultaneously. Thus, fractional designs are efficient to estimate the main effects of each variable studied (Antony, 2014). The experimental design is showed in the first seven columns of Table 1.

\subsection{Osmotic dehydration}

The OD runs were carried out in a system composed by a mini glass reactor that has a jacketed system to maintain the temperature controlled during the process (Figure 1). The apparatus was also sealed to keep sub-atmospheric pressures (vacuum pulse). A vacuum pump (131, Prismatec, Brazil) with a pressure gauge was coupled to the system to ensure pressure control. The temperature of the OD process was controlled using an ultra-thermostatic bath (Q214M2, Quimis, Brazil), which circulated the fluid into the jacketed apparatus. The OD solution circulation was performed using a magnetic bar inside the reactor and placing it over a magnetic stirrer (Q-261, Quimis, Brazil) to guarantee constant stirring. At the circulation speed used, the surface layer around the sample was constantly renewed. The osmotic solutions were prepared according to the fractional factorial design by dissolving sucrose and calcium lactate to distilled water.

Whole fruits of jambolan were defrost at $5^{\circ} \mathrm{C}$ and weighed in the analytical balance at room temperature $\left(\approx 25^{\circ} \mathrm{C}\right)$. After that, the fruits were immersed in the osmotic solution at working temperature and concentration; then, the system was closed and submitted to vacuum pulse, as defined by the fractional design (Table 1). Each assay was performed using the fruit 
Table 1. Fractional factorial design matrix with the original and coded values of independent variables and the experimental results of the dependent variables.

\begin{tabular}{|c|c|c|c|c|c|c|c|c|c|}
\hline \multirow{3}{*}{ Run } & \multicolumn{6}{|c|}{ Independent variables } & \multirow{2}{*}{\multicolumn{3}{|c|}{$\begin{array}{c}\text { Dependent variables } \\
\text { (response values) }\end{array}$}} \\
\hline & \multicolumn{6}{|c|}{ (coded and original values) $^{\mathrm{a}}$} & & & \\
\hline & $\mathrm{x}_{1}$ & $\mathrm{x}_{2}$ & $\mathrm{x}_{3}$ & $\mathrm{x}_{4}$ & $\mathrm{x}_{5}$ & $\mathrm{x}_{6}$ & $\mathrm{WL}$ & SG & WR \\
\hline 1 & $-1(20)$ & $-1(30)$ & $-1(10)$ & $-1(5)$ & $-1(0)$ & $-1(1)$ & -1.06 & -4.51 & 3.45 \\
\hline 2 & $1(50)$ & $-1(30)$ & $-1(10)$ & $-1(5)$ & $1(4)$ & $-1(1)$ & 21.20 & 3.87 & 17.33 \\
\hline 3 & $-1(20)$ & $1(60)$ & $-1(10)$ & $-1(5)$ & $1(4)$ & $1(3)$ & 9.54 & 4.68 & 4.86 \\
\hline 4 & $1(50)$ & $1(60)$ & $-1(10)$ & $-1(5)$ & $-1(0)$ & $1(3)$ & 12.28 & 2.48 & 9.8 \\
\hline 5 & $-1(20)$ & $-1(30)$ & $1(90)$ & $-1(5)$ & $1(4)$ & $1(3)$ & 4.93 & 2.31 & 2.62 \\
\hline 6 & $1(50)$ & $-1(30)$ & $1(90)$ & $-1(5)$ & $-1(0)$ & $1(3)$ & 7.70 & -5.11 & 12.8 \\
\hline 7 & $-1(20)$ & $1(60)$ & $1(90)$ & $-1(5)$ & $-1(0)$ & $-1(1)$ & 5.55 & 0.70 & 4.80 \\
\hline 8 & $1(50)$ & $1(60)$ & $1(90)$ & $-1(5)$ & $1(4)$ & $-1(1)$ & 20.53 & 1.85 & 18.6 \\
\hline 9 & $-1(20)$ & $-1(30)$ & $-1(10)$ & $1(15)$ & $-1(0)$ & $1(3)$ & 6.38 & 1.47 & 4.9 \\
\hline 10 & $1(50)$ & $-1(30)$ & $-1(10)$ & $1(15)$ & $1(4)$ & $1(3)$ & 14.65 & 3.26 & 11.3 \\
\hline 11 & $-1(20)$ & $1(60)$ & $-1(10)$ & $1(15)$ & $1(4)$ & $-1(1)$ & 10.20 & 3.46 & 6.7 \\
\hline 12 & $1(50)$ & $1(60)$ & $-1(10)$ & $1(15)$ & $-1(0)$ & $-1(1)$ & 20.71 & 7.09 & 13.6 \\
\hline 13 & $-1(20)$ & $-1(30)$ & $1(90)$ & $1(15)$ & $1(4)$ & $-1(1)$ & 2.73 & -0.68 & 3.4 \\
\hline 14 & $1(50)$ & $-1(30)$ & $1(90)$ & $1(15)$ & $-1(0)$ & $-1(1)$ & 9.72 & 0.51 & 9.2 \\
\hline 15 & $-1(20)$ & $1(60)$ & $1(90)$ & $1(15)$ & $-1(0)$ & $1(3)$ & 1.93 & -1.25 & 3.18 \\
\hline 16 & $1(50)$ & $1(60)$ & $1(90)$ & $1(15)$ & $1(4)$ & $1(3)$ & 21.35 & 2.85 & 18.4 \\
\hline 17 & $0(35)$ & $0(45)$ & $0(50)$ & $0(10)$ & $0(2)$ & $0(2)$ & 8.10 & 0.47 & 7.63 \\
\hline 18 & $0(35)$ & $0(45)$ & $0(50)$ & $0(10)$ & $0(2)$ & $0(2)$ & 7.16 & 0.59 & 6.57 \\
\hline 19 & $0(35)$ & $0(45)$ & $0(50)$ & $0(10)$ & $0(2)$ & $0(2)$ & 7.53 & -0.25 & 7.75 \\
\hline
\end{tabular}

${ }^{a}$ Values between parentheses are the real forms of the variables. $\mathrm{x}_{1}=$ temperature $\left({ }^{\circ} \mathrm{C}\right) ; \mathrm{x}_{2}=$ sucrose concentration $(\%) ; \mathrm{x}_{3}=$ pressure $(\mathrm{kPa}) ; \mathrm{x}_{4}=$ vacuum pulse time $($ min $) ; \mathrm{x}_{5}=\mathrm{calcium}$ lactate concentration (\%); $\mathrm{x}_{6}=$ number of vacuum pulse; $\mathrm{WL}=$ water loss (\%); $\mathrm{SG}=$ solid gain (\%); $\mathrm{WR}=$ weight reduction (\%).

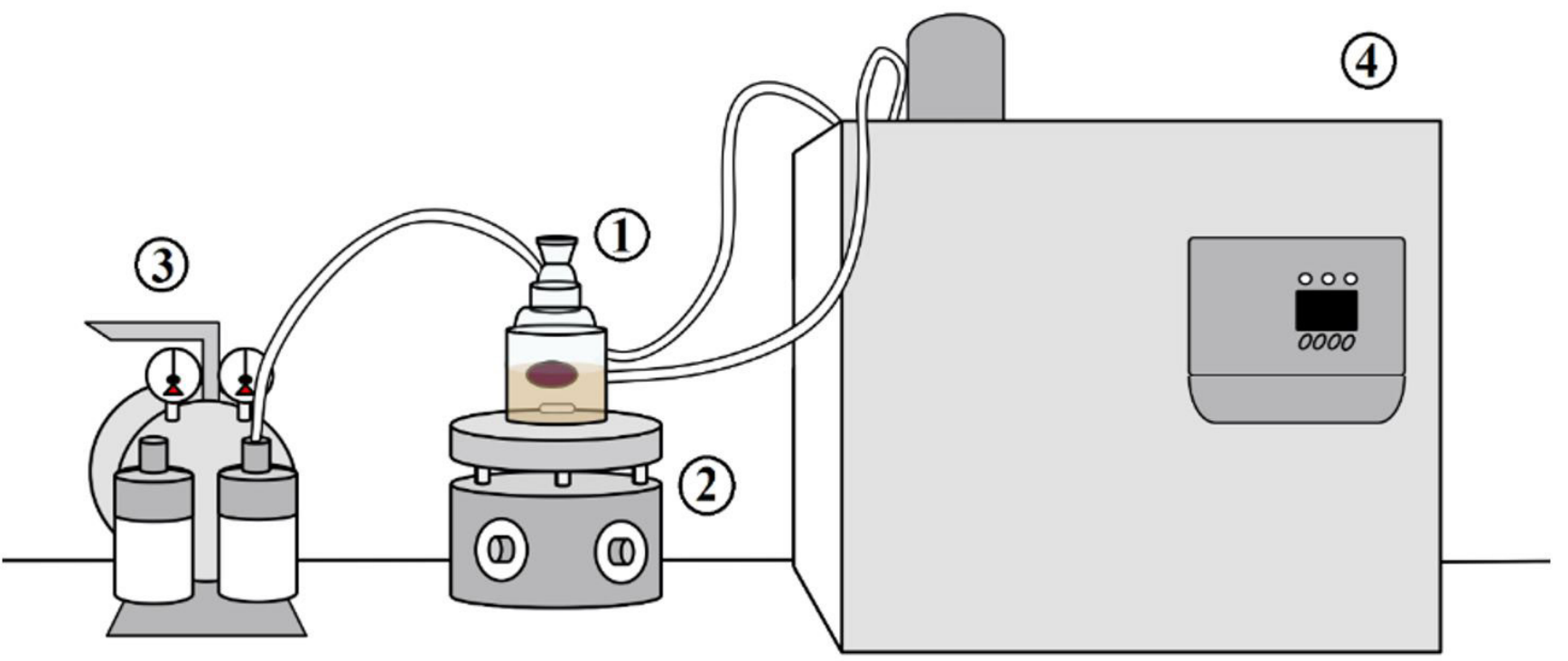

Figure 1. System used in the osmotic dehydration of jambolan composed by a mini glass reactor (1), a magnetic stirrer (2), a vacuum pump (3) and an ultra-thermostatic bath (4).

mass:osmotic solution ratio of $1: 10(\mathrm{~m} / \mathrm{v})$ in order to ensure the constant osmotic solution concentration during the process.

Each treatment of the experiment was subjected to specific pressure and vacuum pulse time. A relaxation time of $15 \mathrm{~min}$ at atmospheric pressure was done between the numbers of pulses. At the end of pressure conditions, the system's vacuum was interrupted and when the total process time (90 $\mathrm{min}$ ) was finished, the samples were removed from the osmotic solution, rinsed with $10 \mathrm{~mL}$ of distilled water and dried for 10 seconds in absorbent paper to remove water and sucrose/calcium lactate in excess from the surface. The osmo-dehydrated samples were weighed in the analytical balance and the moisture was determined before and after the OD process. 


\subsection{Mass transfer determination}

The responses (dependent variables) WL, SG and WR were calculated as described by Sridevi \& Genitha (2012), according to Equations 2-4:

$W L(\%)=\frac{\left(W_{0}-W_{t}\right)}{M_{0}} \times 100$

$S G(\%)=\frac{\left(S_{t}-S_{0}\right)}{M_{0}} \times 100$

$W R(\%)=\frac{\left(M_{0}-M_{t}\right)}{M_{0}} \times 100$

where, $M_{0}=$ initial mass of the sample $(\mathrm{g}) ; M_{t}=$ mass of the sample $(\mathrm{g})$ after dehydration; $\mathrm{W}_{0}=$ initial water mass of the sample $(\mathrm{g})$; $\mathrm{W}_{\mathrm{t}}=$ water mass of the sample $(\mathrm{g})$ after dehydration; $\mathrm{S}_{0}=$ initial dry mass of the sample $(\mathrm{g})$ and $\mathrm{S}_{\mathrm{t}}=$ dry mass of the sample $(\mathrm{g})$ after dehydration.

\subsection{Statistical analysis}

The fruit's biometric data were analyzed by the statistical adjustments of position (mean, minimum and maximum values) and dispersion (standard deviation, coefficient of variation, skewness and kurtosis). The Spearman's correlation coefficients $(\mathrm{rS})$ were estimated at $\mathrm{p} \leq 0.01$, for the association between the biometric characteristics of the fruits.

The main effects of the OD process fractional design were estimated for screening variables. The experimental design was performed at a level of significance of $99 \%(\mathrm{p} \leq 0.01)$, using pure error. Both biometric analysis and OD data were analyzed using the software Statistica (version 7.1, StatSoft Inc., USA).

\section{Results and discussion}

\subsection{Biometric analysis}

The descriptive analysis results for the physical characteristics of the jambolan fruits are presented in Table 2. The mean morphometric dimension values of the fruits were $26.7 \mathrm{~mm}$ for longitudinal diameter (LD) and $17.87 \mathrm{~mm}$ for equatorial diameter (ED). These values are higher than those reported by Albuquerque et al. (2019), who found $22.49 \mathrm{~mm}$ for LD and $16.8 \mathrm{~mm}$ for ED, for the same fruit.

Steiner et al. (2017) observed values of $4.83 \mathrm{~g}, 1.24 \mathrm{~g}$ and $72.93 \%$ for whole fruit weight (WFW), seed fruit weight (SFW) and yield, respectively. These values are also slightly lower than those found in the present work, except for yield (Table 2). The pulp fruit weight (PFW) observed in the study presented a mean value of $4.07 \mathrm{~g}$, which contributed to a yield higher than $70 \%$. This yield value is much higher than the minimum value (40\%) required for products elaboration, mainly for food processing industries (Lira et al., 2005).

The values of skewness closest to zero were $0.06,0.15$ and -0.24 , for WFW, PFW and LD, respectively (Table 2). These findings indicate an approximately normal distribution for the characteristics evaluated, as shown by the frequency distribution (Figure 2a, c and e). The negative kurtosis values found in the present study for WFW and PFW suggests a platykurtic distribution (Ibe, 2014).

The values of the coefficients of variation (CV) for the physical characteristics of the jambolan ranged from $8.61 \%$ (Yield) to $34.66 \%$ (PFW). Lower CV values were reported by Steiner et al. (2017) for the biometric characteristics of jambolan fruits (Syzygium cumini) (5.17-25.94\%). In general, the studied fruits presented greater morphometric characteristics when compared to the fruits found by other authors (Ferraz et al., 2014; Steiner et al., 2017; Albuquerque et al., 2019). These variations observed in the biometric characteristics of jambolan can be attributed to the phenotypic variation, which is influenced by uncontrolled environmental components, such as anthropization conditions, edaphic and climatic factors, plant age and genetic differences (Silva et al., 2001).

The fruits of jambolan presented themselves as oblong, with 19.4 to $34 \mathrm{~mm}$ of LD, 11.1 to $22.7 \mathrm{~mm}$ of ED, 2.1 to $9.43 \mathrm{~g}$ of WFW, 0.64 to $3.09 \mathrm{~g}$ of SFW, 1.45 to $7.08 \mathrm{~g}$ of PFW and yield varying from 53.94 to $85.51 \%$. According to Silva et al. (2012), the non-domesticated plant species present great variability between same matrices on the physical characteristics, such as size, color, number of seeds, weight of seed and pulp, among others.

Regarding the frequency distribution, about $45 \%$ of the fruits presented LD corresponding to 22.54 to $28.16 \mathrm{~mm}$ (Figure 2a) and, approximately, $43 \%$ presented ED in the range of 15.74 to $18.06 \mathrm{~mm}$ (Figure $2 \mathrm{~b}$ ). Close results were found for fruits of

Table 2. Physical characteristics of jambolan fruits.

\begin{tabular}{|c|c|c|c|c|c|c|}
\hline Measurement & Result $^{\mathrm{a}}$ & Minimum & Maximum & Skewness & Kurtosis & $\mathrm{CV}$ \\
\hline $\mathrm{LD}(\mathrm{mm})$ & $26.7 \pm 2.67$ & 19.4 & 34 & -0.24 & 0.71 & 10.0 \\
\hline $\mathrm{ED}(\mathrm{mm})$ & $17.87 \pm 1.93$ & 11.1 & 22.7 & -0.48 & 0.74 & 10.8 \\
\hline WFW (g) & $5.66 \pm 1.67$ & 2.1 & 9.43 & 0.06 & -0.75 & 29.43 \\
\hline SFW (g) & $1.59 \pm 0.38$ & 0.64 & 3.09 & 0.38 & 1.64 & 23.88 \\
\hline PFW (g) & $4.07 \pm 1.41$ & 1.45 & 7.08 & 0.15 & -0.81 & 34.66 \\
\hline Yield (\%) & $70.74 \pm 6.09$ & 53.94 & 85.51 & -0.66 & 0.26 & 8.61 \\
\hline
\end{tabular}

a Data refer to mean values $(\mathrm{n}=100) \pm$ standard deviation. $\mathrm{LD}=$ longitudinal diameter $(\mathrm{mm})$; EQ = equatorial diameter $(\mathrm{mm})$; WFW = whole fruit weight $(\mathrm{g})$; SFW = seed fruit weight (g); PFW = pulp fruit weight $(\mathrm{g}) ; \mathrm{CV}=$ coefficient of variation $(\%)$. 
jambolan in the study of Ferraz et al. (2014), who demonstrated that approximately $44 \%$ of the LD showed values between 20.90 to $25.40 \mathrm{~mm}$, and around $49 \%$ of the ED presented values varying from 14.90 to $16.40 \mathrm{~mm}$.

For the subsequent biometric characteristics, the highest frequency values were in the range of 5.03 to $6.49 \mathrm{~g} \mathrm{(30 \% )} \mathrm{for}$ WFW (Figure 2c), 1.62 to $2.11 \mathrm{~g}$ (43\%) for SFW (Figure 2d), 2.57 to $3.70 \mathrm{~g}(30 \%)$ for PFW (Figure $2 \mathrm{e}$ ) and 72.88 to $79.19 \%$
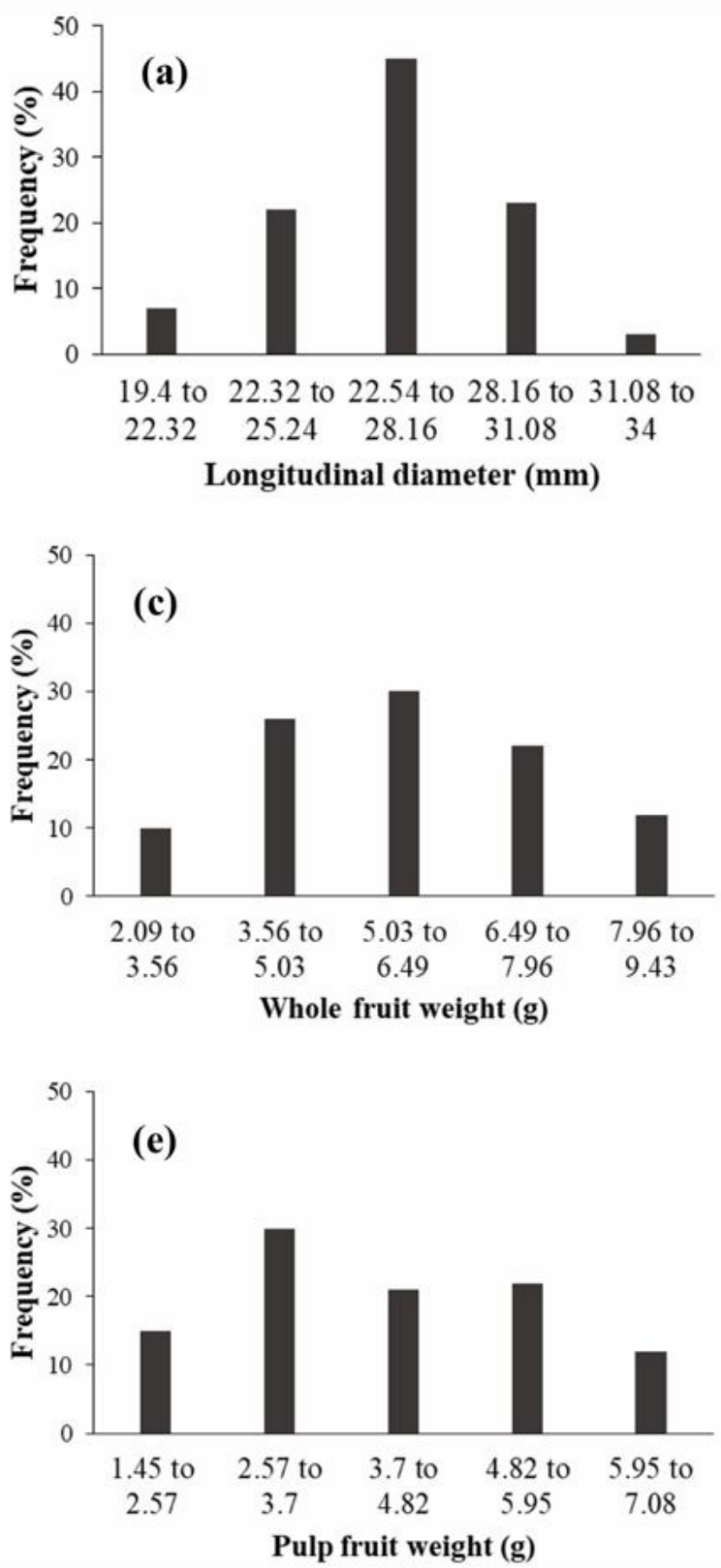

(41\%) for yield (Figure 2f). A considerable amount of jambolan fruits $(\approx 95 \%)$ presented yield above $60 \%$ (Figure $2 \mathrm{f}$ ), which is higher than the results observed by Albuquerque et al. (2019), who found a mean yield value of $57.22 \%$, for the same fruit.

The association among the physical characteristics is also important because it allows verifying the interference between the factors (Liu, 2017). In this sense, the Spearman's rank correlation coefficient (rS) is used to express the degree of association
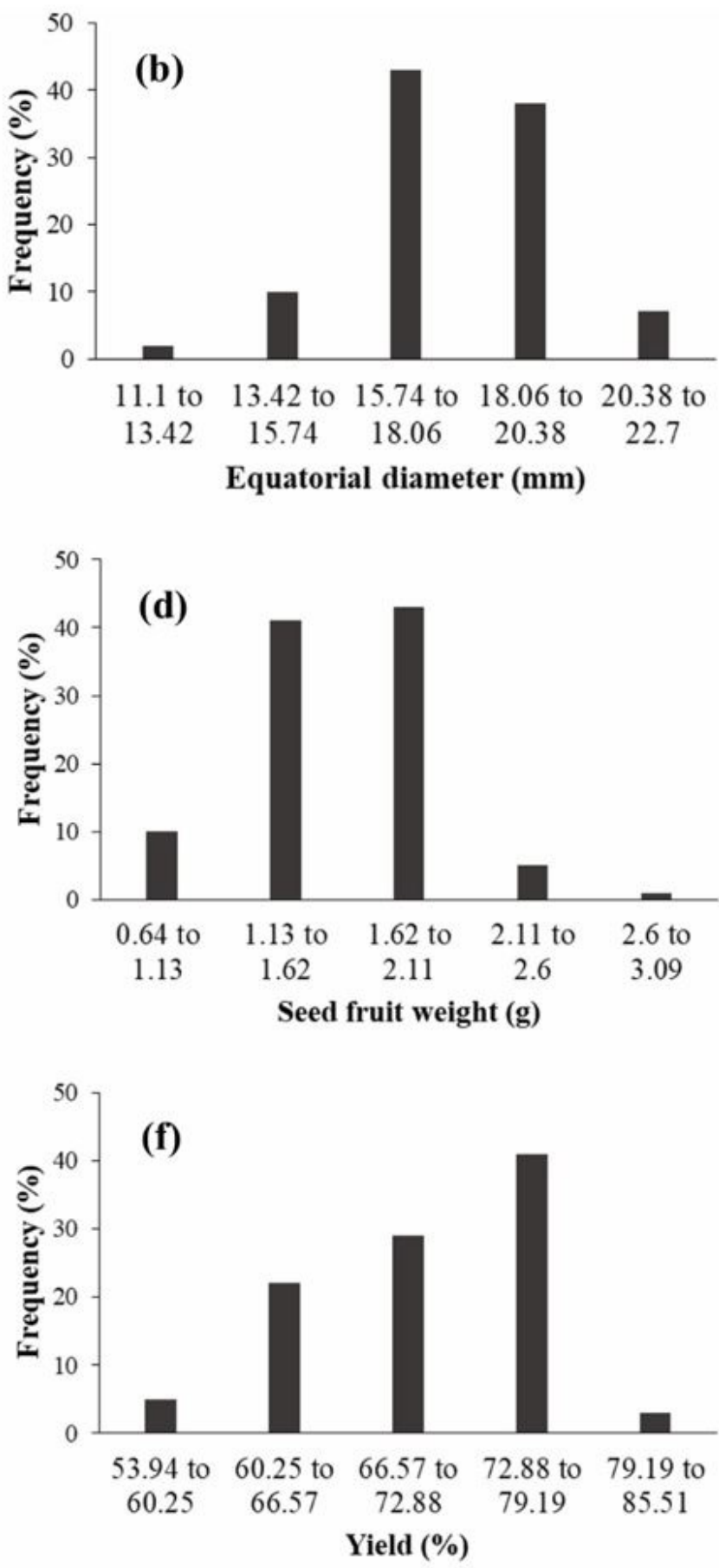

Figure 2. Distribution of frequencies for the different physical characteristics of the fruits measured. 
between two numerical characteristics. A positive or negative value corresponds, respectively, to an increasing or decreasing monotonic trend between two variables (Shaw et al., 2017).

Table 3 shows a positive and significant correlation for all physical variables of the jambolan fruits, with the exception of the correlation between yield and SFW. The highest value of the Spearman's rank correlation coefficients $(\mathrm{rS})$ was observed for PFW vs WFW ( $\mathrm{rS}=0.98 ; \mathrm{p} \leq 0.01$ ). In this sense, an increase in WFW is desirable for the economic exploitation of jambolan, since it tends to increase the PFW and, consequently, increases the edible part of the fruit. Thus, the results have shown that it is possible to identify and select jambolan fruits with higher pulp yield based on other biometric characteristics (WFW, LD and ED).

In this context, the fruits' morphological characterization is fundamental to provide information for the handling, packaging, advanced stages of commercial and industrial exploitation, as well as assisting on the machinery and equipment design (Steiner et al., 2017). Besides, the knowledge of the biometric variation of fruits is important for the creation of germplasm banks and for the improvement of these characteristics, in the sense of fruit's increasing or uniforming. It can also be explored by breeding programs directed to the generation of cultivars that provide fruits with important features in order to improve the commercialization (Gonçalves et al., 2013).

\subsection{Physical-chemical, chemical and color evaluation of jambolan}

The fresh fruits of jambolan harvested from the Amazon region were characterized as acidic fruits $(\mathrm{pH}=3.87 \pm 0.04)$, presenting a total tritatable acidity value of $1.22 \pm 0.02$ (g citric acid. $100^{-1} \mathrm{~g}$ ). Moreover, the most abundant component of the fruit is moisture $\left(84.62 \pm 0.26 \mathrm{~g} \cdot 100^{-1} \mathrm{~g}\right)$, followed by carbohydrates $\left(13.90 \pm 0.03 \mathrm{~g} \cdot 100^{-1} \mathrm{~g}\right)$. Although high acidity and low $\mathrm{pH}(<4.0)$ can limit microbial growth in the product (Lara, $2019)$, the high moisture and $\mathrm{a}_{\mathrm{w}}(0.98 \pm<0.01)$ values, as well as the reducing sugars content $\left(8.19 \pm 0.17 \mathrm{~g} .100^{-1} \mathrm{~g}\right)$, favor the degradative processes in the fruits of jambolan. Other minority components in the fruit are ashes $\left(0.43 \pm 0.01 \mathrm{~g} .100^{-1} \mathrm{~g}\right)$, total proteins $\left(0.48 \pm 0.05 \mathrm{~g} \cdot 100^{-1} \mathrm{~g}\right)$ and total lipids $\left(0.56 \pm 0.03 \mathrm{~g} .100^{-1} \mathrm{~g}\right)$. These results are similar to those reported by other authors (Brito et al., 2017; Albuquerque et al., 2019).

The studied jambolan fruits were shown to be a promising source of total phenolics $\left(391 \pm 18.89 \mathrm{mg} \mathrm{GAE} \cdot 100^{-1} \mathrm{~g}\right)$ with

Table 3. Spearman's rank correlation coefficient (rS) between the different physical characteristics of jambolan fruits.

\begin{tabular}{clllll}
\hline Characteristic & LD & ED & WFW & SFW & PFW \\
\hline ED & $\mathbf{0 . 7 2}$ & & & & \\
WFW & $\mathbf{0 . 8 2}$ & $\mathbf{0 . 8 5}$ & & & \\
SFW & $\mathbf{0 . 7 9}$ & $\mathbf{0 . 6 8}$ & $\mathbf{0 . 7 4}$ & & \\
PFW & $\mathbf{0 . 7 6}$ & $\mathbf{0 . 8 3}$ & $\mathbf{0 . 9 8}$ & $\mathbf{0 . 6 0}$ & \\
Yield & $\mathbf{0 . 3 1}$ & $\mathbf{0 . 4 8}$ & $\mathbf{0 . 6 2}$ & -0.03 & $\mathbf{0 . 7 4}$ \\
\hline
\end{tabular}

Bold characters indicate that the corresponding parameter has a significant effect $(\mathrm{p} \leq 0.01) . \mathrm{LD}=$ longitudinal diameter $(\mathrm{mm}) ; \mathrm{ED}=$ equatorial diameter $(\mathrm{mm})$; WFW = whole fruit weight $(\mathrm{g}) ;$ SFW = seed fruit weight $(\mathrm{g}) ;$ PFW = pulp fruit weight (g). levels higher than those found in studies for the same fruit by Rufino et al. (2010) (185 mg GAE.100-1 g) and Albuquerque et al. (2019) (182.01 mg GAE.100 ${ }^{-1} \mathrm{~g}$ ). The total phenolics present in fruits are one of the main compounds responsible for their antioxidant activity. Thus, as food components, phenolic compounds play roles in imparting the color (especially anthocyanin, a class of flavonoids), having sensory features as well, and acting as food preservatives (Singh et al., 2018).

Besides their food coloring roles, anthocyanins are also important antioxidant sources and take fundamental part on helping prevent many degenerative diseases (Khoo et al., 2017). Albuquerque et al. (2019), when studying anthocyanin content in fresh jambolan found values of $93.56 \mathrm{mg} \cdot 100^{-1} \mathrm{~g}$. Rufino et al. (2010) determined the anthocyanins content of several fruits from the Myrtaceae family, including camu-camu $\left(42.2 \mathrm{mg} \cdot 100^{-1} \mathrm{~g}\right)$,

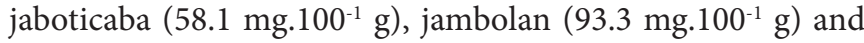
murta $\left(143 \mathrm{mg} \cdot 100^{-1} \mathrm{~g}\right)$. These findings are slightly below from those observed in the present study $\left(147 \pm 1.85 \mathrm{mg} \cdot 100^{-1} \mathrm{~g}\right)$. Such differences may be explained by several climatic and edaphic factors (Brito et al., 2017).

The color parameters for the jambolan fruit denote low values of lightness $\left(L^{*}=32.34 \pm 0.18\right)$ and chroma $\left(C^{*}=16.80 \pm 2.93\right)$; the values found for $a^{\star}(16.80 \pm 2.93$, red color $), b^{\star}(-0.29 \pm 0.08$, blue color) and $h^{\circ}(359.02 \pm 0.03$, pure red) located the fruit in the CIELAB space corresponding to the purple-red color region. These findings corroborate to those observed by Brito et al. (2017), for the same fruit.

\subsection{Osmotic dehydration of jambolan}

The jambolan fruits selected for OD process were chosen based on the interval of the highest frequencies for LD (22.54-28.16 mm) (Figure 2a), ED (15.74-18.06 mm) (Figure 2b) and WFW (5.03-6.49 g) (Figure 2c). The experimental results of water loss (WL), solid gain (SG) and weight reduction (WR) for the OD of jambolan, from the fractional factorial design, are presented in the Table 1 (columns eight to ten). The highest WL values (> 20\%) occurred at the maximum temperature $(\mathrm{T})$ and calcium lactate $(\mathrm{CC})$ or sucrose (SC) concentration levels (runs 2, 8, 12 and 16). In contrast, the lowest WL value (run 1) occurred at the minimum levels of all independent variables, in which an undesirable swelling effect (water gain) was observed.

In general, the WL (-1.06-21.35\%) was much higher than the SG (-5.11-7.09\%), and this phenomenon could be explained by the formation of a dense layer of solutes at the surface of the osmo-dehydrated jambolan, acting as a barrier against solutes penetration into the food, making solutes mass transfer more difficult, which probably has resulted in a lower solids uptake inside the fruit tissue (Giraldo et al., 2003). According to Torreggiani (1993), in the OD process, the WL must be favored with a minimum SG. Nevertheless, SG should be enough for preservation but not so high to induce sensory and nutritional changes in the product (Delgado et al., 2018).

In addition, high WR (2.62-18.69\%) values were attributed to high WL values, in most of the assays, because there was a greater amount of water getting out from the fruit tissue (mass 
loss) than solute entrancing (mass gain). This behavior occurs in preserved tissue because the selective permeability of the cell membranes allows the transport of small molecules, such as water. However, it can restricts the transport of larger molecules, such as sucrose, and hence reduce the diffusion of sucrose through the cell tissue (Silva et al., 2014).

A useful tool to identify the most important factors affecting an experiment is the Pareto chart. This graph shows the main effects estimate plotted against a horizontal axis. The main effects are ranked according to their significance order and a vertical line is used to indicate the threshold p-value for statistical significance (Loukas, 2001). In this sense, the fractional factorial design was employed to analyze the intensity of the effects and its significance instead of model validation. Thus, the Figure 3 shows the Pareto chart of each effect estimate for the dependent variables (responses).

\subsection{Effect on the percentage of water loss}

From the Figure $3 \mathrm{a}$, the significant effects that contributed positively with WL were $\mathrm{T}, \mathrm{CC}$ and $\mathrm{SC}(\mathrm{p} \leq 0.01)$. The $\mathrm{T}$ was the main variable affecting $\mathrm{WL}$. These results are in agreement with Alam et al. (2010), who studied the OD of Indian gooseberry and verified that $\mathrm{T}$ influenced significantly the WL. Mercali et al. (2010) reported that high temperatures could promote a fast WL due to the plasticizing and swelling effects that occur in cell membranes, as well as the faster water diffusion in the product due to the lower viscosity of the osmotic medium.

The second most important factor in WL of jambolan was CC. OD added calcium has been used in an attempt to increase firmness and enhance the selective effect of sucrose transfer, restricting the SG and increasing WL (Mavroudis et al., 2012). Close results were found by Silva et al. (2014), who observed that the addition of $4 \%$ calcium lactate significantly increased the WL of pineapple at all processing times.

High SC also favored the WL, and this fact seems to be based on the increase in osmotic gradient between the food material and the osmotic solution. The existence of a large amount of solute causes a higher osmotic pressure that makes the WL easier (Corrêa et al., 2010). These results corroborate
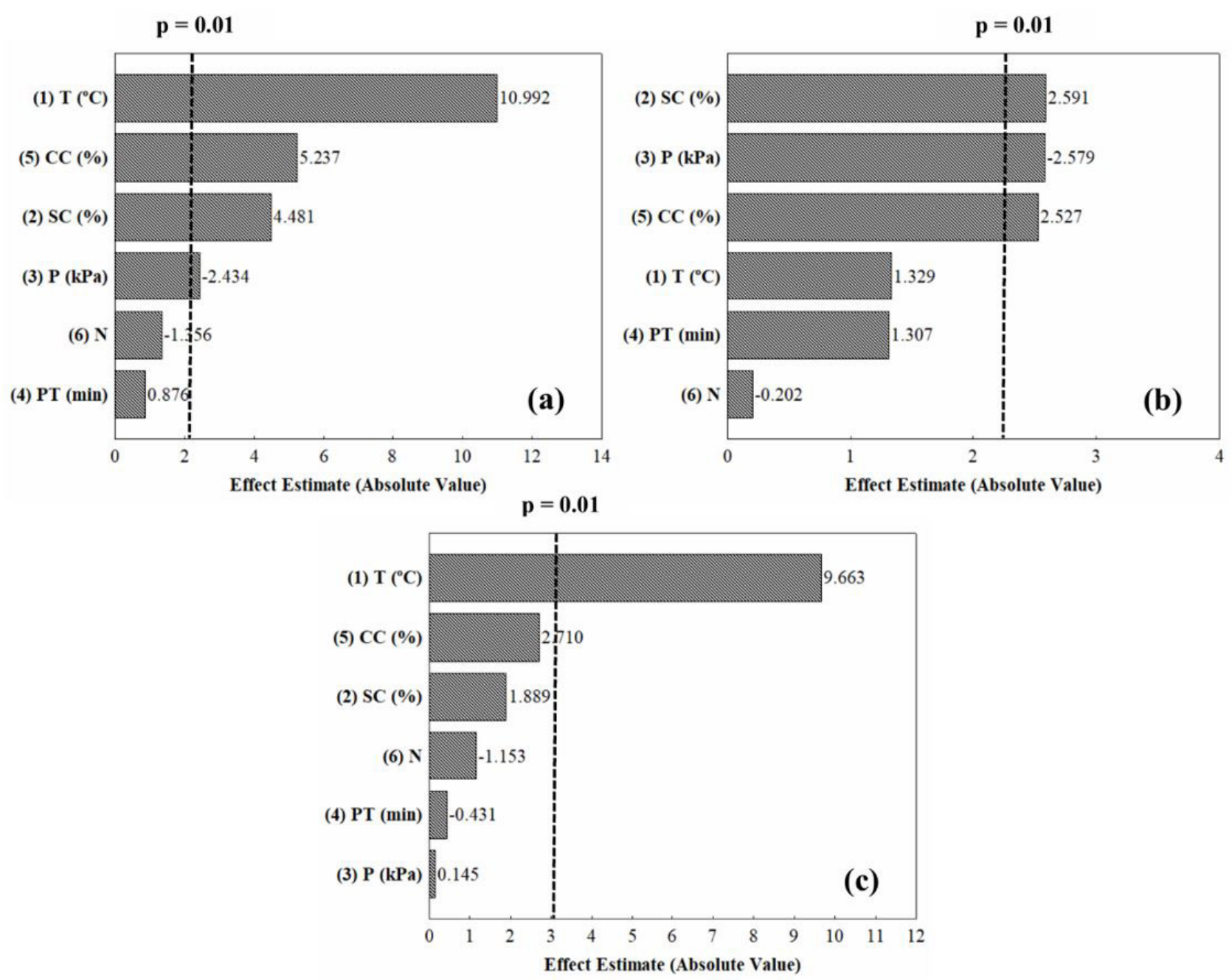

Figure 3. Effect estimate (absolute values) for water loss (a), solid gain (b) and weight reduction (c). $\mathrm{T}=$ temperature $\left({ }^{\circ} \mathrm{C}\right)$; $\mathrm{SC}=$ sucrose concentration (\%); $\mathrm{P}=$ pressure $(\mathrm{kPa}) ; \mathrm{PT}=$ vacuum pulse time $(\mathrm{min}) ; \mathrm{CC}=$ calcium lactate concentration $(\%) ; \mathrm{N}=$ number of vacuum pulse. 
to those obtained by Porto et al. (2014), who studied the OD of Crimson seedless grape and observed that the SC had a positive influence on the WL content.

The WL increase in jambolan is also attributed to the application of low pressures $(\mathrm{P})$, as explained by the hydrodynamic mechanism (HDM), in which outflow induced in the fruit tissue is the result of the compression of sample volume provoked by the pressure change, implying on the liquid exit from the fruit with subsequent acceleration of WL (Chiralt \& Fito, 2003). Similar behavior was observed Corrêa et al. (2015), who demonstrated that $\mathrm{P}$ was the variable with the smallest influence on WL in OD of sliced tomato.

\subsection{Effect on the percentage of solid gain}

The variables SC, $\mathrm{P}$, and CC presented similar influence on SG (Figure 3b), at 99\% level of significance. SG was affected positively by SC ( $\mathrm{p} \leq 0.01)$ and, according to Phisut (2012), an increase in SG with SC is due to the high concentration gradient between the sample and the osmotic solution, which increases the diffusion rate of solute. Furthermore, the increased mass transfer of sugar molecules with the increase in concentration is possible due to the membrane swelling effect that increases the permeability of the membrane. Thus, by choosing a higher concentrated medium a much greater SG is observed. These findings are in accordance with those found by Siqueira et al. (2019), for $\mathrm{OD}$ of ginger.

The negative effect of $\mathrm{P}$ on $\mathrm{SG}(\mathrm{p} \leq 0.01)$ suggests that the use of high pressures decreases the response. Thus, the lower the pressure (high vacuum) the higher the SG. The gain of solid attributed to vacuum pulse can also be explained by the HDM and, therefore, when vacuum conditions are applied, the gas occluded inside the intercellular spaces of vegetable tissues is removed. Once the atmospheric pressure condition is restored, the pores of the food material are filled by osmotic solution, increasing the available mass transfer surface area (Corrêa et al., 2010).

Shi et al. (1995) reported that osmotic treatments performed with the application of vacuum are effective on WL rates, but its influence on SG is only evidenced in highly porous fruits, once SG is intrinsically related to the micro structural characteristics of the cellular tissue, such as porosity. Corrêa et al. (2010) noticed that the use of $15 \mathrm{~min}$ of vacuum pulse $(10 \mathrm{kPa})$ at the beginning of the OD process caused an increase in the $S G$ of guavas.

However, regarding the positive influence of CC on SG observed in the study, the overall SG among the assays (Table 1) was not expressive ( $S G<7.09)$. Other studies, as pointed by Silva et al. (2014), found that the OD of pineapple in sucrose solutions added calcium lactate significantly reduced the incorporation of sugar in the fruit and denoted that the presence of this salt tends to restrict the gain in sucrose. Similar behavior was noted by Mavroudis et al. (2012) who observed that the SG in apples decreased with the addition of $0.6 \%$ calcium lactate to the solution, and attributed the result to a reduction in cell wall porosity.

\subsection{Effect on the percentage of weight reduction}

Figure $3 \mathrm{c}$ demonstrates that $\mathrm{T}$ was the only significant variable affecting WR $(\mathrm{p} \leq 0.01)$, which had a positive effect. The WR exhibits a mass relationship among the whole flows involved in the osmotic process, mainly between WL and SG (El-Aouar et al., 2006), but in this study WR was more attributed to WL instead of SG (Table 1). The effect of T on WR is because its increments favor the exit of water from the fruit (Bekele \& Ramaswamy, 2010). Some researchers have observed the same influence of T over WR, involving OD studies in pineapple (Sridevi \& Genitha, 2012) and chestnut slices (Delgado et al., 2018). The WR, which indirectly measures the water reduction in the osmotic dehydrated product, is an important variable in the transportation and storage of great product volumes (Zapata et al., 2016).

Regarding to the variables PT and N, no significant effect was found ( $\mathrm{p} \leq 0.01)$ among all the studied responses (WL, SG and WR). A research involving PT (5-15 min), at the beginning of the process, have pointed its positive effect on SG in $5 \mathrm{~h}$ of osmotic process, despite no influence of this variable being found below this period of time for any response, in the OD of mango (Ito et al., 2007). In other research, Zapata et al. (2016) studied the influence of $\mathrm{N}$ on the OD of Cape gooseberry and have demonstrated no effect of this variable over WL, SG and WR.

The results show that the OD is a suitable technological alternative to reduce post-harvest losses of jambolan fruits. In this sense, this fruit could be dehydrated to save part of the production that is not destined for immediate consumption or exportation, providing its shelf life extension. In addition, to improve the control of this unitary operation, the present work has contributed for the selection of variables that significantly influence the OD process of jambolan.

Thus, the fractional factorial design has collaborated on screening the experiments in which effects of all independent variables were examined simultaneously, identifying efficiently variables that are, in fact, important for the process. Moreover, the present study gives subsides for researches to rearrange the minimum and maximum levels of the variables in further $\mathrm{OD}$ experiments and optimization studies can be formulated from the information generated by this preliminary design.

\section{Conclusion}

Osmotic dehydration (OD) of jambolan was studied for the first time. The biometric analysis show that the pulp yield of jambolan is directly proportional to the dimensions and weight, and inversely proportional to the seed weight of the fruits. The pulp and skin represent more than $70 \%$ of the whole fruit weight, also is a potential source of bioactive compounds, which is favorable for its economic exploitation, as in OD process. The screening design shows that temperature, pressure, calcium lactate concentration and sucrose concentration have influence over the osmotic process, considering water loss as the most important property in OD. On the other hand, vacuum pulse time and number of vacuum pulse showed no influence on the OD process; therefore, these variables can be fixed at the most 
economically viable level for any further trials. The presence of calcium lactate minimized the solute uptake in the cell tissue of the jambolan, controlling the solid gain in the product. Thus, future optimization studies can be formulated from the present fractional factorial design.

\section{Acknowledgements}

The authors are thankful for the financial support provided by the Conselho Nacional de Desenvolvimento Científico e Tecnológico (CNPq, Brazil) (422739/2016-2), CAPES for the scholarship of A. L. Araújo (01602743207), and PROPESP (UFPA, Brazil).

\section{References}

Ahmed, I., Qazi, I. M., \& Jamal, S. (2016). Developments in osmotic dehydration technique for the preservation of fruits and vegetables. Innovative Food Science \& Emerging Technologies, 34, 29-43. http:// dx.doi.org/10.1016/j.ifset.2016.01.003.

Alam, M. S., Amarjit, S., \& Sawhney, B. K. (2010). Response surface optimization of osmotic dehydration process for aonla slices. Journal of Food Science and Technology, 47(1), 47-54. http://dx.doi. org/10.1007/s13197-010-0014-4. PMid:23572600.

Albuquerque, G. A., Carvalho, A. V., Faria, L. J. G., Chisté, R. C., Martins, L. H. S., \& Lopes, A. S. (2019). Effects of thermal pasteurization on jambolan tropical juice bioactive compounds. British Food Journal, 121(11), 2821-2834. http://dx.doi.org/10.1108/BFJ-03-2019-0191.

Antony, J. (2014). Design of experiments for engineers and scientists: fractional factorial designs (2nd ed.). London: Elsevier Science.

Association of Official Analytical Chemists - AOAC. (2002). Official methods of analysis of AOAC international (17th ed.). Washington.

Bekele, Y., \& Ramaswamy, H. S. (2010). Going beyond conventional osmotic dehydration for quality advantage and energy savings. Ethiopian Journal of Applied Science and Technology, 1(1), 1-15.

Brito, B. N. C., Pena, R. S., Lopes, A. S., \& Chisté, R. C. (2017). Anthocyanins of Jambolão (Syzygium cumini): extraction and $\mathrm{pH}$-dependent color changes. Journal of Food Science, 82(10), 2286-2290. http://dx.doi. org/10.1111/1750-3841.13847. PMid:28833121.

Carvalho, I. M., Nogueira, T. Y. K., Mauro, M. A., Gómez-Alonso, S., Gomes, E., Da-Silva, R., Hermosín-Gutiérrez, I., \& Lago-Vanzela, E. S. (2017). Dehydration of jambolan [Syzygium cumini (L.)] juice during foam mat drying: quantitative and qualitative changes of the phenolic compounds. Food Research International, 102, 32-42. http://dx.doi.org/10.1016/j.foodres.2017.09.068. PMid:29195954.

Chiralt, A., \& Fito, P. (2003). Transport mechanisms in osmotic dehydration: the role of the structure. Food Science \& Technology International, 9(3), 179-185. http://dx.doi.org/10.1177/1082013203034757.

Corrêa, J. L. G., Dantas, V. A., Mendonça, K. S., \& Justus, A. (2015). Optimization of pulsed vacuum osmotic dehydration of sliced tomato. Drying and Energy Technologies, 63, 207-228. http://dx.doi. org/10.1007/978-3-319-19767-8_11.

Corrêa, J. L. G., Pereira, L. M., Vieira, G. S., \& Hubinger, M. D. (2010). Mass transfer kinetics of pulsed vacuum osmotic dehydration of guavas. Journal of Food Engineering, 96(4), 498-504. http://dx.doi. org/10.1016/j.jfoodeng.2009.08.032.

Delgado, T., Paim, B., Pereira, J. A., Casal, S., \& Ramalhosa, E. (2018). Optimization of osmotic dehydration of chestnut (Castanea sativa Mill.) slices using response surface methodology. International Journal of Food Studies, 7, 52-68. http://dx.doi.org/10.7455/ijfs/7.1.2018.a5.
El-Aouar, A. A., Azoubel, P. M., Barbosa, J. L. Jr., \& Murr, F. E. X. (2006). Influence of the osmotic agent on the osmotic dehydration of papaya (Carica papaya L.). Journal of Food Engineering, 75(2), 267-274. http://dx.doi.org/10.1016/j.jfoodeng.2005.04.016.

Ferraz, Y. T., Reis, A. T. S., \& Souza, N. S. (2014). Attributes of influence biometrics on income of squash jamelão (Syzygium jambolanum DC.) in Capitão Poço/PA. Enciclopédia Biosfera, 10(19), 1179-1187.

Food and Agriculture Organization of the United Nations - FAO. (2003). Food energy: methods of analysis and conversion factors (77th ed.). Rome.

Giraldo, G., Talens, P., Fito, P., \& Chiralt, A. (2003). Influence of sucrose solution concentration on kinetics and yield during osmotic dehydration of mango. Journal of Food Engineering, 58(1), 33-43. http://dx.doi.org/10.1016/S0260-8774(02)00331-X.

Gonçalves, L. G. V., Andrade, F. R., Marimon, B. H. Jr., Schossler, T. R., Lenza, E., \& Marimon, B. S. (2013). Biometry of fruits and seeds mangaba (Hancornia speciosa Gomes) in natural vegetation in the eastern region of Mato Grosso, Brazil. Ciência Agronômica, 36(1), 31-40.

Ibe, O. C. (2014). Introduction to descriptive statistics. In O. C. Ibe (Ed.), Fundamentals of applied probability and random processes (Chap. 8, pp. 253-274). USA: Elsevier Academic Press. http://dx.doi. org/10.1016/B978-0-12-800852-2.00008-0.

Instituto Nacional de Meteorologia - INMET. (1992). Normais climatológicas. Retrieved from http://www.inmet.gov.br/portal/ index.php?R=bdmep/bdmep

Ito, A. P., Tonon, R. V., Park, K. J., \& Hubinger, M. D. (2007). Influence of process conditions on the mass transfer kinetics of pulsed vacuum osmotically dehydrated mango slices. Drying Technology: An International Journal, 25(10), 1769-1777. http://dx.doi. org/10.1080/07373930701593263.

Kapoor, S., Ranote, P. S., \& Sharma, S. (2015). Bioactive components and quality assessment of jamun (Syzygium cumini L.) powder supplemented chapatti. Indian Journal of Science and Technology, 8(3), 287-295. http://dx.doi.org/10.17485/ijst/2015/v8i3/59863.

Khoo, H. E., Azlan, A., Tang, S. T., \& Lim, S. M. (2017). Anthocyanidins and anthocyanins: colored pigments as food, pharmaceutical ingredients, and the potential health benefits. Food \& Nutrition Research, 61(1), 1361779. http://dx.doi.org/10.1080/16546628.201 7.1361779. PMid:28970777.

Lara, W. (2019). Factors affecting the growth and survival of microorganisms in foods. In W. Lara (Ed.), Food science and quality control (Chap. 5, pp. 115-121). United Kingdom: ED-Tech Press.

Lees, D. H., \& Francis, F. J. (1972). Standardization of pigment analyses in cranberries. Horticultural Science, 7, 83-84.

Lira, J. S. Jr., Musser, R. S. M., Enayde, A., Maciel, M. I. S., Lederman, I. E., \& Santos, V. F. (2005). Physical and physico-chemical caracterization of "cajá-umbu" fruits. Food Science and Technology, 25(4), 757-761.

Liu, L. (2017). Biostatistical basis of inference in heart failure study. In L. Liu (Ed.), Heart failure: epidemiology and research methods (Chap. 4, pp. 43-82). USA: Elsevier Academic Press.

Loukas, Y. L. (2001). Plackett-Burmam screening design directs the efficient formulation of multicomponent DRV liposomes. Journal of Pharmaceutical and Biomedical Analysis, 26(2), 255-263. http:// dx.doi.org/10.1016/S0731-7085(01)00419-8. PMid:11470202.

Mavroudis, N. E., Gidley, M. J., \& Sjöholm, I. (2012). Osmotic processing: effects of osmotic medium composition on the kinetics and texture of apple tissue. Food Research International, 48(2), 839-847. http:// dx.doi.org/10.1016/j.foodres.2012.06.034. 
Mercali, G. D., Tessaro, I. C., Noreña, C. P. Z., \& Marczak, L. D. F. (2010). Mass transfer kinetics during osmotic dehydration of bananas (Musa sapientum, Shum.). International Journal of Food Science \& Technology, 45(11), 2281-2289. http://dx.doi.org/10.1111/j.1365-2621.2010.02418.x.

Miller, G. L. (1959). Use of dinitrosalicylic acid reagent for determination of reducing sugars. Analytical Chemistry, 31(3), 426-428. http:// dx.doi.org/10.1021/ac60147a030.

Phisut, N. (2012). Factors affecting mass transfer during osmotic dehydration of fruit. Food Research International, 19(1), 7-18.

Porto, M. A. L., Guerra, N. B., Vasconcelos, M. A. S., Siqueira, A. M. O., \& Andrade, S. A. C. (2014). Optimisation of osmotic dehydration in the Crimson Seedless grape. Ciência Agronômica, 45(2), 249-256. http://dx.doi.org/10.1590/S1806-66902014000200004.

Rufino, M. S. M., Alves, R. E., Brito, E. S., Pèrez-Jiménez, J., SauraCalixto, F., \& Mancini-Filho, J. (2010). Bioactive compounds and antioxidant capacities of 18 non-traditional tropical fruits from Brazil. Food Chemistry, 121(4), 996-1002. http://dx.doi.org/10.1016/j. foodchem.2010.01.037.

Sari, P., Wijaya, C. H., Sajuthi, D., \& Supratman, U. (2012). Colour properties, stability, and free radical scavenging activity of jambolan (Syzygium cumini) fruit anthocyanins in a beverage model system: natural and copigmented anthocyanins. Food Chemistry, 132(4), 1908-1914. http://dx.doi.org/10.1016/j.foodchem.2011.12.025.

Seraglio, S. K. T., Schulz, M., Nehring, P., Della Betta, F., Valese, A. C., Daguer, H., Gonzaga, L. V., Fett, R., \& Costa, A. C. O. (2018). Nutritional and bioactive potential of Myrtaceae fruits during ripening. Food Chemistry, 239, 649-656. http://dx.doi.org/10.1016/j. foodchem.2017.06.118. PMid:28873617.

Shaw, P. A., Johnson, L. L., \& Proschan, M. A. (2017). Intermediate topics in biostatistics. In J. Gallin, F. Ognibene \& L. L. Johnson (Eds.). Principles and practice of clinical research (Chap. 4, pp. 383409). USA: Academic Press.

Shi, X. Q., Fito, P., \& Chiralt, A. (1995). Influence of vacuum treatment on mass transfer during osmotic dehydration of fruits. Food Research International, 28(5), 445-454. http://dx.doi.org/10.1016/09639969(96)81391-3.

Silva, K. S., Fernandes, M. A., \& Mauro, M. A. (2014). Effect of calcium on the osmotic dehydration kinetics and quality of pineapple.
Journal of Food Engineering, 134, 37-44. http://dx.doi.org/10.1016/j. jfoodeng.2014.02.020.

Silva, M. A., Silva, C. E. A., Mariani, V. C. B., \& Darche, S. (2012). Mass transfer during the osmotic dehydration of West Indian cherry. Lebensmittel-Wissenschaft + Technologie, 45(2), 246-252. http:// dx.doi.org/10.1016/j.lwt.2011.07.032.

Silva, R. S. M., Chaves, L. J., \& Naves, R. V. (2001). Caracterization of cagaita (Eugenia dysenterica DC.) fruits and tree in southeastern region of Goias State, Brazil. Revista Brasileira de Fruticultura, 23(2), 330-334. http://dx.doi.org/10.1590/S0100-29452001000200026.

Singh, B., Singh, J. P., Kaur, A., \& Singh, N. (2018). Insights into the phenolic compounds present in jambolan (Syzygium cumini) along with their health-promoting effects. International Journal of Food Science \& Technology, 53(11), 1-17. http://dx.doi.org/10.1111/ijfs.13841.

Singh, C. S., Paswan, V. K., \& Rai, D. C. (2019). Process optimization of spray dried Jamun (Syzygium cumini L.) pulp powder. LebensmittelWissenschaft + Technologie, 109, 1-6. http://dx.doi.org/10.1016/j. lwt.2019.04.011.

Singleton, V. L., \& Rossi, J. A. (1965). Colorimetry of total phenolic with phosphomolybdic-phosphotungstic acid reagents. American Journal of Enology and Viticulture, 16(3), 144-158.

Siqueira, L. P., Sarubbo, L. A., Shinohara, N. K. S., Valencia, M. S., Cortez, N. M. S., \& Andrade, S. A. C. (2019). Optimization of the osmotic dehydration of ginger. Ciência Rural, 49(10), 1-7. http:// dx.doi.org/10.1590/0103-8478cr20170430.

Sridevi, M., \& Genitha, E. T. R. (2012). Optimization of osmotic dehydration process of pineapple by response surface methodology. Journal of Food Processing \& Technology, 3(8), 441-448.

Steiner, F., Zuffo, A. M., \& Zoz, T. (2017). Physical characterization of fruits and seeds of jambolan [Syzygium cumini (L.) Skeels] (Myrtaceae). Acta Iguazu, 6(3), 79-90.

Torreggiani, D. (1993). Osmotic dehydration in fruit and vegetable processing. Food Research International, 26(1), 59-68. http://dx.doi. org/10.1016/0963-9969(93)90106-S.

Zapata, J. E. M., Ciro, G. L. G., \& Marulanda, P. L. (2016). Optimization of pulsed vacuum osmotic dehydration of the Cape gooseberry (Physalis peruviana L.) using the response surface methodology. Agronomia Colombiana, 34(2), 228-238. http://dx.doi.org/10.15446/ agron.colomb.v34n2.54920. 